\title{
Simulation-Based Analysis of Greenhouse Gas Emissions in Sustainable Supply Chains-Re-Design in an Approach to Supply Chain Strategy
}

\author{
Blanka Tundys *(D) and Tomasz Wiśniewski (D) \\ Management Institute, University of Szczecin, 71-004 Szczecin, Poland; tomasz.wisniewski1@usz.edu.pl \\ * Correspondence: blanka.tundys@usz.edu.pl
}

check for updates

Citation: Tundys, B.; Wiśniewski, T.

Simulation-Based Analysis of

Greenhouse Gas Emissions in Sustainable Supply Chains-

Re-Design in an Approach to Supply

Chain Strategy. Energies 2021, 14, 3504

https://doi.org/10.3390/en14123504

Academic Editor: Almas Heshmati

Received: 4 May 2021

Accepted: 8 June 2021

Published: 12 June 2021

Publisher's Note: MDPI stays neutral with regard to jurisdictional claims in published maps and institutional affiliations.

Copyright: (c) 2021 by the authors. Licensee MDPI, Basel, Switzerland. This article is an open access article distributed under the terms and conditions of the Creative Commons Attribution (CC BY) license (https:/ / creativecommons.org/licenses/by/ $4.0 /$ )

\begin{abstract}
The aim of the study was to analyze emissions in the supply chain and to identify, based on a literature analysis, which supply chain strategies could contribute to reducing these emissions. A broad spectrum of new supply chain strategy solutions was identified and, based on simulations of selected products, conclusions were drawn and the advantages and disadvantages of theoretical solutions were presented for individual cases. A critical analysis of the literature and simulation methods were used to illustrate the problem presented in this paper, to identify the factors causing greenhouse gas emissions and to draw conclusions in the form of proposals to redesign existing strategies, considering the factors determining the increase in pollution caused by the performed logistics processes. The results of the simulations and the literature analysis indicate that solutions related to the redesign of strategies must consider the specificity of the product and the nature of the chain. Not all proposed strategies are applicable to all chains, and each new strategy must be carefully considered and consider many factors. An important element to reduce the negative environmental impact of chains is a well-thought-out relationship with suppliers, a well-chosen and adapted logistics infrastructure, including means of transport. The presented solutions clearly indicate that the environmental aspect plays an increasingly important role in chain management and influences the applied chain strategies. However, reducing the environmental impact of a chain is not a revolutionary approach and an easy-to-implement strategy change, but a well-thought-out, longterm process that considers the specifics of the products, the possibilities of alternative sourcing and distribution modes, and the need to invest in logistics infrastructure to make it as environmentally neutral as possible.
\end{abstract}

Keywords: greenhouse gas emissions; supply chain; simulation-based analysis

\section{Introduction}

Environmental issues are one of the top priorities for countries (macroeconomic aspect) as well as for companies (microeconomic aspect) and their supply chains (metaeconomic aspect). Reducing the negative impact of human activities on all ecosystems requires efforts and coherent solutions related to the development of environmental awareness, reorganisation, and implementation of changes in supply chain management. Actually, in almost all industry sectors, organisations are introducing new initiatives and practices to act more consciously for the environment [1]. The emission of greenhouse gases into the atmosphere is a specific and globally perceptible effect of logistics activities. More and more stringent legal regulations for eco-efficiency are being introduced administratively, at the level of individual economies or within the framework of international regulations [2], including carbon tax, and cap and trade-the European Union Emission Trading System [3]. Practically, all economic activities generate emissions of pollutants, to varying degrees and extents, considering different mechanisms for generating negative environmental impacts [4], and the actual volume of these emissions depends on the logistical decisions taken [5]. 
Considering the global interconnectedness of production and consumption sites, it is important to point out that the pollution that occurs during the transport and storage of freight is a major problem, and is one of the most important elements in the carbon footprint of the chain. It is therefore necessary to carry out research along the supply chain to identify which processes are the least environmentally neutral and how to reduce the negative environmental impact of the chain. Research on green, sustainable, responsible or ecological supply chains has been going on for many years [6]. Their theoretical backgrounds and specific focus on environmental aspects and sustainability are intended to contribute to reducing the negative impacts of logistics processes along the chain and redefining the strategies adopted, and should contribute to complying with sustainable development requirements [7]. It therefore seems necessary to adapt and reconfigure supply chain strategies to reduce this impact as far as possible. Moreover, reducing emissions from supply chains should be a strategic imperative for every organisation [8].

The following discussion will be based on an indication of the impact of supply chains on GHG (greenhouse gasses) emission using a simulation method and its iterations from the point of view of different chain types, different products and points of origin distances. On this basis, managerial implications are indicated, including different options and possibilities for reconfiguring the chain strategy that can contribute to reducing its negative environmental impact.

The main motivation for undertaking research on this topic was its relevance to the development of not only new business strategies, but above all the possibility of constructing environmentally friendly chains using simulation methods. On their basis, by analysing specific solutions and supply chains, it is possible to draw conclusions for managers and support decision-making processes. The subject of changes in chain strategies has already been described in the literature [9], but not in such a context, identifying individual processes and their environmental impacts in selected supply chains and developing a simulation model. Consideration is given to the use of models for changes in food supply chains [10] and whether decision making works under uncertainty [11], optimization methods are also indicated [12] or a theoretical approach and analysis of supply chain optimization method selection [13]. This means that the topic is already being addressed and should be explored further to be able to develop the best possible models for configuring the chains.

The novelty of our considerations is the identification on the basis of the literature and presentation of new possible supply chain strategies, which, in combination with the implementation of the sustainable development principles, will constitute a starting point for the reconfiguration of previously applied solutions. The simulation approach we used was to show the negative effects of logistics activities along supply chains and to draw attention to how important the choice of chain management strategy is. The amount and type of pollution that will be emitted to the environment depends on it. The topic is extremely important, not only in the context of global environmental pollution, which results, inter alia, from the performance of logistics processes, but also because of the need to reconfigure the strategy of supply chains. The classical approach, based on the cost-quality-time relationship, does not quite work nowadays. It is necessary to add the environmental aspect to this triad and consider it as one of the priorities to achieve the standard classical goals of organizations and their supply chains. By identifying new, more environmentally friendly supply chain strategies, and building simulation models that indicate the level and location of pollutant emissions, we can build chains in the future that will bring win-win benefits to all stakeholders and mother nature. The contribution to the development of the discipline, and the novelty of the results of this research, is based on the collection and presentation of the most important pro-environmental chain strategies and the analysis of processes negatively affecting the environment (simulations), to propose further directions for the development of supply chains, including the awareness of the existing risks and the need to shorten current chains. 
The paper is structured as follows: Section 2 indicates the research questions, hypotheses and main objectives of the paper; Section 3 refers, in a theoretical way, to the possibilities of reconfiguring supply chains, with particular emphasis on the environmental aspect, low-carbon and shortening supply chains, as well as the description of the negative impact of chains on the environment (greenhouse gases); Section 4 is the research methodology followed by the simulation results. Section 5 is the findings and discussion, in which the advantages and disadvantages of the different solutions for reconfiguring strategies and the possibilities for their implementation are indicated, and Section 6 summarises the results of the research and the issues discussed, as well as indicating recommendations for reconfiguring chains.

\section{Research Questions and Aims}

Using mathematical models as well as computer simulations, it is possible to provide supply chain managers with effective decision support tools for reconfiguring supply chains in an easy, clear and transparent way. Changes in the strategy must meet requirements and global economic trends, which means that solutions must be proposed to make chains increasingly environmentally neutral, with low-carbon management and the implementation of sustainability principles. Therefore, it is possible to hypothesise that the traditional long supply chains, whose management is based on economic efficiency, contribute to an increase in the negative environmental impacts of the chain, mainly due to the length of the chains and the use of non-environmentally neutral means of transport for the processes, and the failure to put environmental aspects on an equal footing with economic objectives. The management of such chains does not consider environmental aspects as one of the basic paradigms of modern management and conducting business in line with global trends. Therefore, basing the chain strategy on the economic and cost aspect does not meet the environmental requirements of modern economies. This configuration is economically efficient, but not environmentally. In view of the above, the following research questions were posed: Can the use of modern logistics infrastructure have positive effects and reduce negative impacts on the environment without abandoning existing chain strategies? Does the reconfiguration of the chain, changing strategies and creating short supply chains promote environmental neutrality? Can the above assumptions be generalised and applied to different types of chains, or will the approach depend on the nature of the product and its chain? How, then, can supply chains be managed so that their negative impact on the environment is reduced? Is the short-chain implementation always the optimal one? Finally, one more question arises, which is particularly topical, and relates to the certainty of the execution of processes in global supply chains and the impact of the disruption of chains due to unforeseen situations (the COVID-19 pandemic, blockage of the Suez Canal) in terms of the environment and changes in chain strategies. This question regards whether such events affect the environmental aspect in the implementation of logistics processes.

In the considerations, a simulation method was chosen to indicate the need for changing chain strategies and chain management approaches. Thanks to it, several scenarios can be considered, and the easily implemented changes and modifications clearly show the influence of individual factors on the reconfiguration of chains. Jet is a method commonly used in supply chain research [14-16].

\section{Reconfiguration of Supply Chain Strategy in the Context of Environmental Impact-A Theoretical Aspect}

The global economic interdependence of supply chains causes the greenhouse gas emissions of logistics processes to reach enormous proportions. The inefficiency of the supply chain to eliminate its carbon footprint results in it accounting for more than $80 \%$ of greenhouse gas emissions, and more than $90 \%$ of the impacts on air, land, water, biodiversity and geological resources [17]. Only the USA freight and transportation sector is responsible for the following emissions: more than half of nitrous oxides total emissions, more than $30 \%$ of volatile organic compounds emissions, and over $20 \%$ of particulate matter emissions [18]. 
At the same time, the share of product transport in global freight is constantly increasing. Supply chains are complex and long, and for many companies transport is the largest source of emissions in supply chains. Given these trends, the growth in GHG air emissions from freight transport is projected to outpace the growth in emissions from all other transport activities, including passenger transport. This situation makes it necessary to take measures that contribute to reducing the carbon footprint of chains, including changing existing chain strategies or investing in modern infra- and suprastructures to support logistics processes.

In the context of the chain, it should be taken into account that it is not only transport and its processes that cause gas emissions and carbon footprints. Negative impacts are created by producers, distributors, or consumers themselves (Figure 1), i.e., all market actors. A holistic approach to end-to-end supply chain management and an understanding of where the carbon footprint is greatest in the chain should lead to better, more accurate decisions that transcend a single company or geographic region. Coordinated decision making across supply chains, including optimising strategic and operational supply chain decisions by considering the performance and assessment of pollutant emissions [1], should be a success factor in the struggle for environmental neutrality of activities.

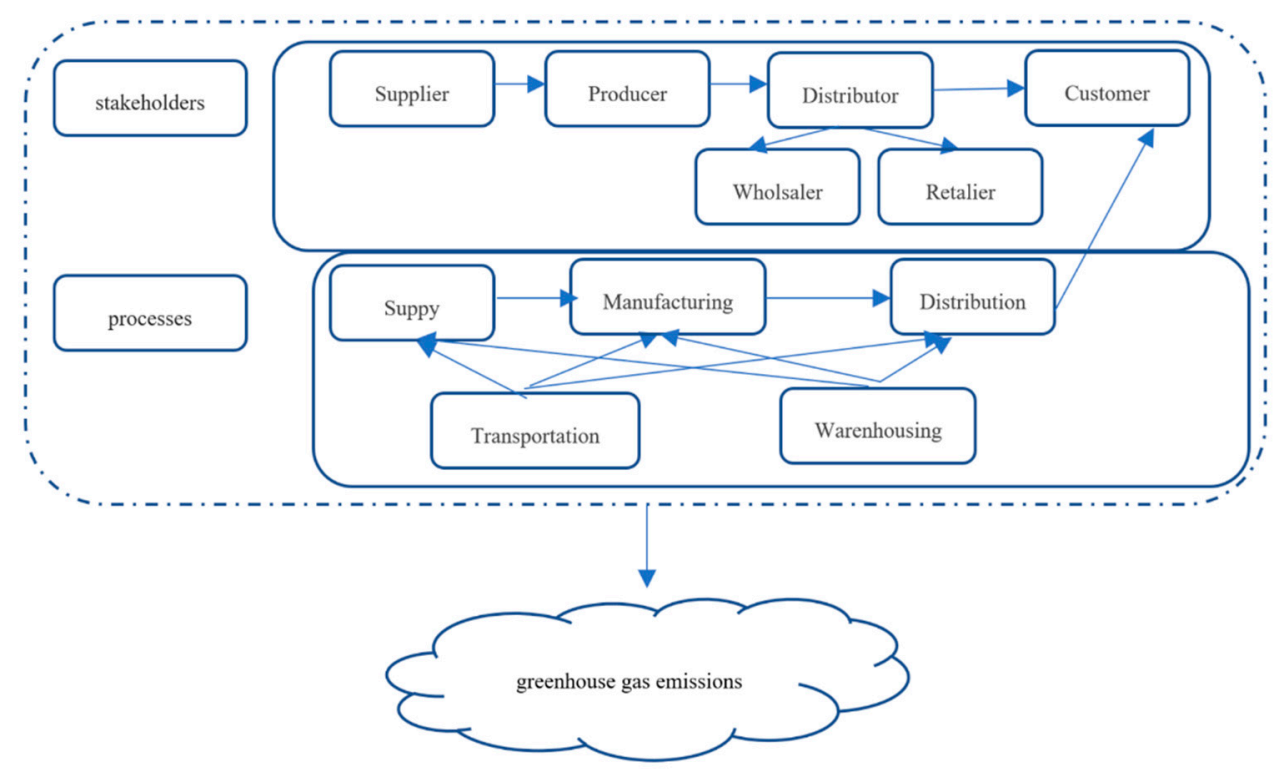

Figure 1. Identification of stakeholders and processes with the impact of GHG emission. Source: own elaboration.

Emissions are attributed to all industrial activities, to varying extents, and are generated in different ways [4]. All stakeholders can and should influence the reduction in GHG emissions, as well as coordinate, promote and enforce sustainability indicators in the supply chain. This can be done through appropriate process coordination or far-reaching investments to support the environmental performance of processes and chains [19].

The literature identifies various solutions for the possibility of reducing pollution in chains. The authors will present a selection of these that can be successfully applied in empirically studied chains. More than three-quarters of greenhouse gas emissions originate from supply chains serving different types of economic sectors [20]. Under the terms of the Kyoto protocol, greenhouse gas emissions include carbon dioxide $\left(\mathrm{CO}_{2}\right)$, methane $\left(\mathrm{CH}_{4}\right)$, nitrous oxide $\left(\mathrm{N}_{2} \mathrm{O}\right)$ and the following three fluorinated gases: hydrofluorocarbons (HFCs), perfluorocarbons (PFCs) and sulphur hexafluoride $\left(\mathrm{SF}_{6}\right)$ [21]. Figure 2 shows a framework that relates the types of pollution to the supply chain processes. All logistics processes and the accompanying processes performed in supply chains have an impact on the environment, and in some cases and strategies it is decidedly negative. The responsibility of individual processes for the types of pollution varies. By taking a holistic approach 
and evaluating the supply chain as a whole, it is possible to just identify the different types of pollution in individual processes. Excessive industrial activity, resulting, among other things, from short product life cycles and a large amount of packaging, including the generation of a large amount of waste, with a simultaneous low level of operating costs, does not take into account, or only to a very limited extent, the socio-environmental costs, and there is consent or acceptance for the emission of harmful substances into the atmosphere. Therefore, we should gradually begin to create a new model of the supply chain that takes into account the natural, social and economic space in which it is embedded. The biggest polluter of the environment is carbon dioxide $\left(\mathrm{CO}_{2)}\right)$. It is mainly formed during the combustion of heavy fuel oils as well as diesel fuels. $\mathrm{CO}_{2}$ emissions are directly related to the amount of fuel burned. Nitrogen oxide $\left(\mathrm{NO}_{\mathrm{x}}\right.$ ) and sulphur dioxide $\left(\mathrm{SO}_{2)}\right)$, among others, are also harmful. Logistics relies heavily on transport vehicles, which are among the biggest polluters of the environment, and these processes accompany all activities undertaken in the supply chain, and emit pollution as shown in Figure 1.

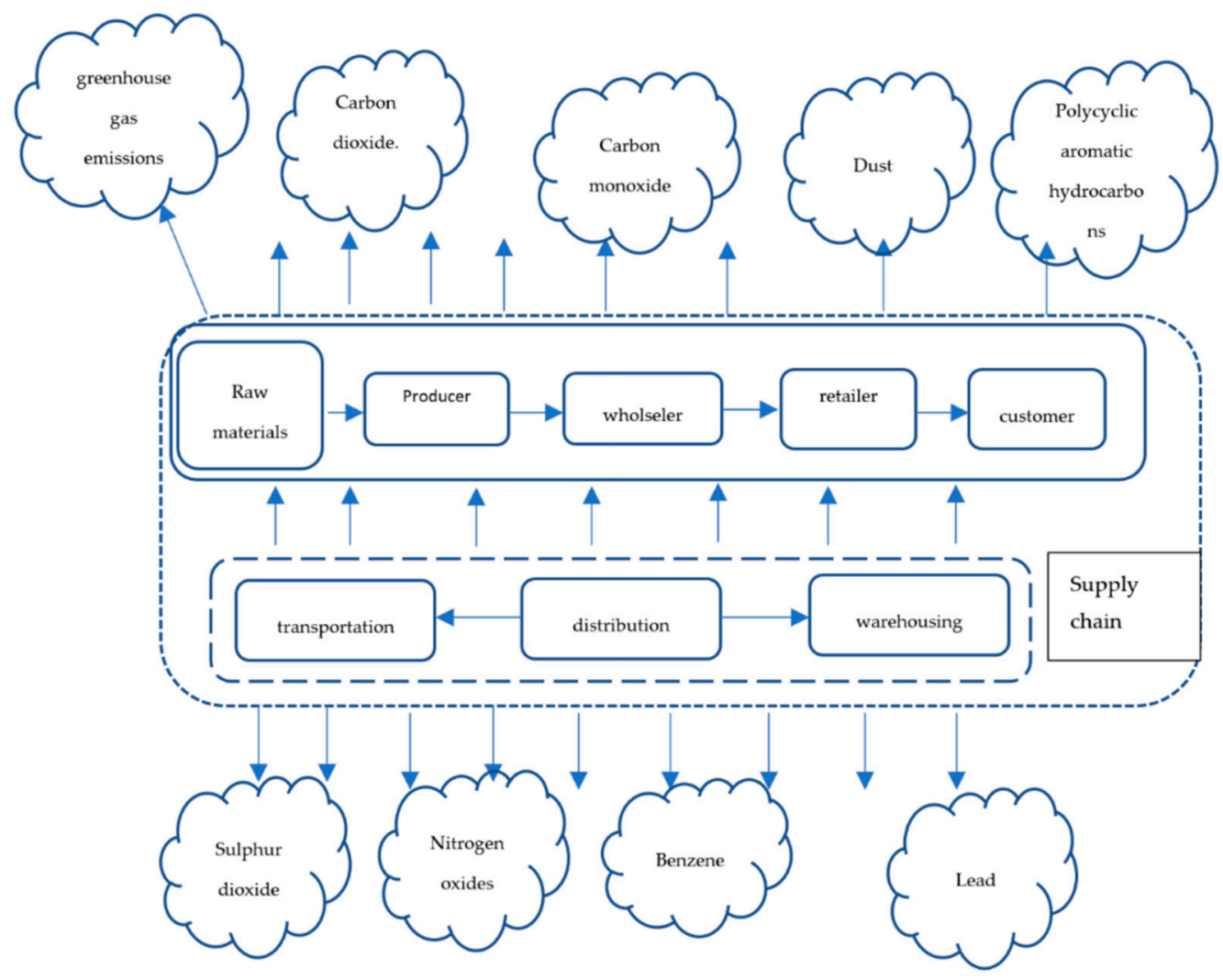

Figure 2. Framework of a simplified supply chain and its components responsible for greenhouse gas emissions. Source: own elaboration.

There are many solutions to the greening chain. It is therefore necessary to consider the theoretical possibilities of reconfiguring chains towards more environmentally neutral chains. At the same time, supply chains and the processes that take place in them operate in an increasingly dynamic and unstable environment, and the level of risk and uncertainty of performing processes as intended is constantly increasing. New risks, hitherto unknown to a large extent, are appearing, which negatively influence the efficiency of processes in chains. The prevention of threats to liquidity and timeliness of supply should go hand in hand with care for the environment. Measures taken to mitigate the risk of threats to the functioning of the chain should be implemented simultaneously with changes in the environmental strategy.

A sustainable supply chain strategy, which by definition promotes pro-environmental actions, considering environmental and social aspects throughout the chain, pays attention 
to balancing processes and products by adopting sustainability objectives for chain management [22]. However, this is a very broad issue. Research in this area analyses the 3BL (triple-bottom line) perspective, pointing to the dominant role of economic and environmental aspects [23]. At the same time, it should be noted that social aspects are receiving more and more attention [24], and this fully reflects the ideas of sustainable development.

From a scientific point of view, in the context of new and innovative solutions for the supply chain strategy, the concept of LCSCM-low carbon supply chain management. The focus is on the following two perspectives: one is on the functional and operational aspects of supply chain management, such as procurement, production and planning, distribution, network design and supply chain coordination; the other is accounting and conceptualisation on carbon footprint (CF) [25] - Figure 3. The main activities in this type of chain include supplier selection, inventory planning, transport management, network design and coordination strategy. The main objective of LCSCM is to reduce the total carbon footprint of the supply chain without compromising the economic interests of the company. Trade-offs between economic and environmental objectives should therefore be sought in all supply chain functions.

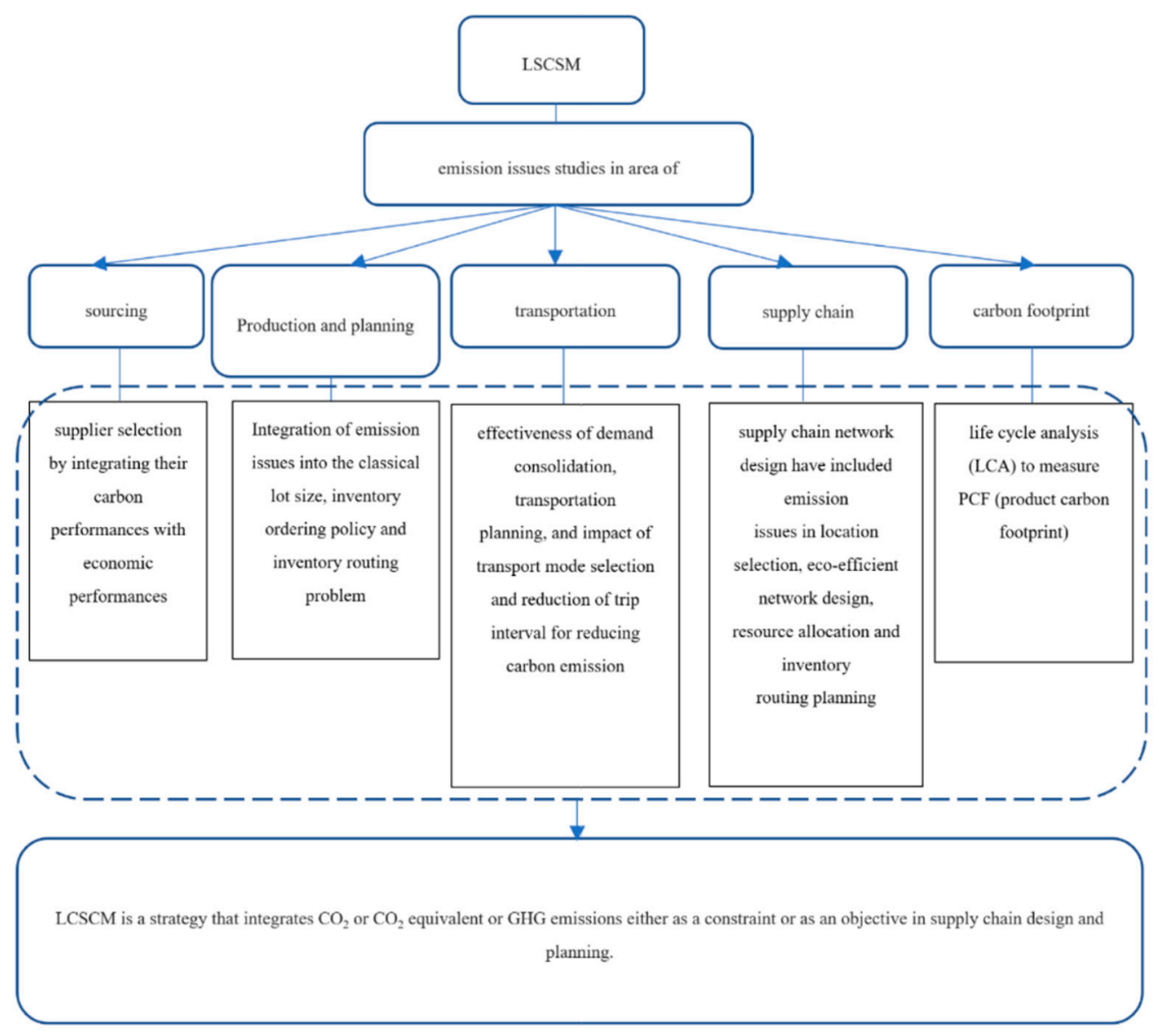

Figure 3. LCSCM framework. Source: own elaboration on the basis of [25].

The strategy can be developed and applied to the two aspects of chain design and chain execution. In both cases, actions should be taken that influence the reduction in the carbon footprint caused by the supply chain (Figure 4). LSCM is also a strategic, environmentally focused initiative, whose main objective is to improve operations and reduce costs by paying more attention to energy efficiency and $\mathrm{CO}_{2}$ reduction [26]. This type of chain should be considered as a possibility to reduce carbon emissions in the operations of product development, the production process, and logistics [27]. The reduction in carbon emissions, in terms of per unit revenue, operations, fees for carbon discharge, production 
process, and overall emissions [28] of LCSCM practices relate to, inter alia, the design of low-carbon products, reduction in production-related GHG emissions, carbon management system [29], and consumption and recycling to consider environmental impacts and resource utilization comprehensively, meanwhile taking suppliers and customers into consideration [30]. It is also worth mentioning that the scope of the LCSCM includes selling and consumption, regarding environmental protection as its main goal [31]. At the same time, it should be pointed out that environmental effects are indisputable, but they should also be linked to economic effects, which are not always obvious. The implementation of the LSCM strategy can also be seen in the context of achieving a competitive advantage on the market through environmentally neutral processes.

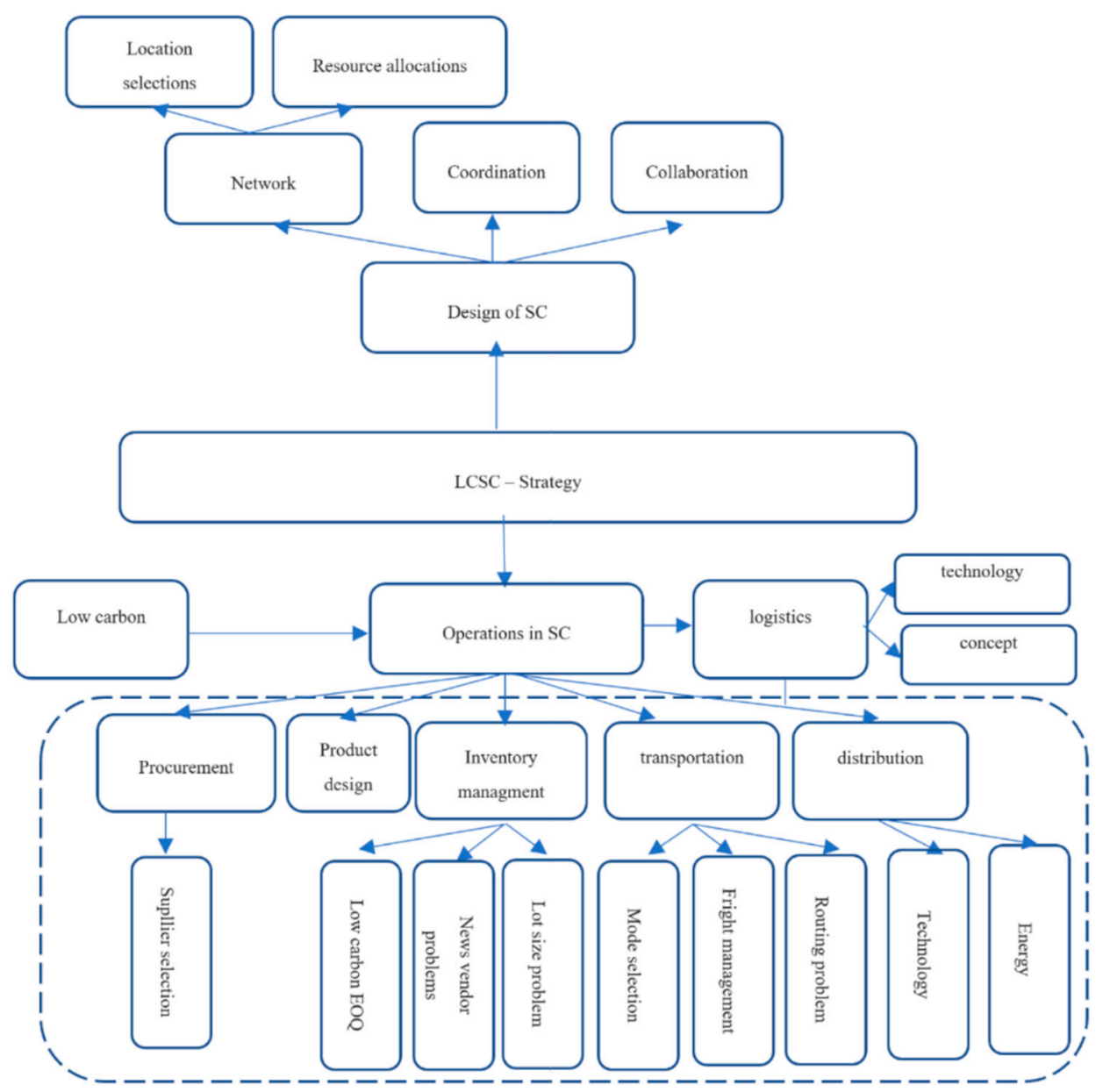

Figure 4. LSC Strategy — design and operation of supply chain. Source: own elaboration on the basis of $[27,32]$.

The LCSCM strategy should be considered together with the green supply chain management (GSCM) strategy, although both focus on different elements and they are to each other complementary, but can also be implemented separately. GSCM is a broader concept, including other elements that address the negative impacts of supply chain processes, not only the reduction in the carbon footprint. It generally refers to respect for the environment $[33,34]$. In the context of the GSCM, it should be pointed out that in terms of chain performance assessment, the perspective is changing from the economic to the green economy, which by definition is moving towards low carbon [35]. The green supply chain includes processes that are green, such as designing, material selection, manufacturing, recycling, packaging and consumption, and other ways. It was possible to achieve the aim, where there would be non-waste production and zero emissions in the whole process, and they maximized the elimination of the impact on the environment [36]. 
Issues of sustainability in the supply chain have long been of interest to researchers. Many scientific publications have been produced, both defining the [37], bibliometric analysis [38], ordering survey methods and quantitative models [39], and related practices [40]. The majority of greenhouse gas emissions associated with products are linked to their chains [41]. It is therefore worth using sustainable development methods and tools to create this type of strategy, and integrate this type of practice into the chain's activities, as most of them go beyond the boundaries of the organisations themselves, thus requiring linking, decision making and action at chain level [42]. The topic of GHG impacts on individual supply chain processes, with a focus on green and sustainable chains, has also been covered quite extensively [43]. In this context, it is important that chains are designed to take into account elements of sustainable development, resources and energy usage efficiency, manufacturing effectiveness and reliability, transportation and consumption, carbon footprints, waste management, and reverse logistics valuations [44]. The implementation of sustainable practices is a priority in the design, as well as in the implementation of sustainable supply chains [45].

A newly developed strategy, and least described in the literature, and therefore creating a research and solution gap, is the short supply chain strategy and the positive effects it can create in terms of GHG impacts. The negative effects of the actions taken, which are increasingly frequent, severe and impossible to predict by chain managers, contribute to decisions on adjustments and the redesign of chain strategies. A compromise and offensive solution consists in shortening the length of the chain and searching for alternative sources of supply close to the places of consumption, which predestines above all the implementation of food supply chain solutions. It is not an ideal solution, it has its weaknesses (described later), but it becomes a kind of alternative to long, traditional supply chains. The assumptions of the strategy are described in the literature, indicating that consumers are increasingly interested in buying organic food, often from local producers or directly. This approach indicates a change (strengthening) in the relationship between the producer and consumer, moving towards more just, social and fair practices [46]. The assumption and implication of such chains is that locally produced food can be more economically, environmentally and socially sustainable than such conventional [47]. At the same time, researchers have pointed out that the direct environmental impact of SFSC may be higher due to the chain structure, and the small number of products offered and distributed, which translates directly into one vehicle or unit of energy. This type of solution also has weaknesses (limited variety, lack of consumer confidence and demand, supply problems and disruptions). Therefore, the concept aims to reduce negative impacts, but it has to be developed in order to meet all the requirements of the consumers, decisionmakers and stakeholders in the chain, because in terms of environmental performance one cannot forget that economic, time and quality aspects must also be considered. Thus, when analysing the literature, it is possible to point out that the solution is coherent with solutions supporting environmental protection; however, as it is a new concept, there is not yet full confidence in it and its scope of influence is limited, and the structure itself does not always show aspects of full optimality. The conceptual foundations of this approach point to a minimum number of intermediaries, organisational proximity, close proximity or sociological implications. The benefits of reducing transport or spreading sustainable farming practices are emphasised [48-50]. Solutions implemented in short supply chains offer the potential to change typically industrial modes of production, shortening long, complex, and in many places industrialised supply chains in which an increasingly smaller share of value-added is identified and attributed to farmers [51]. When considering this type of supply chain, one must certainly take the following into account: the environmental dimension, which is defined as greenhouse gas emissions, the degree of environmental performance of the product, the level of energy savings, and the negative impact on the environment, as well as the fact that these chains are nowadays mostly dedicated to food [52]. 
In the context of the development of new strategies for the chain, and the study of its environmental impact and emissions, energy efficiency measures can be introduced and implemented. By integrating the different activities in the chain, not only better financial performance, but also energy savings and efficiency can be achieved [53], and this implies environmental efficiency through lower emissions. The literature increasingly points to the need to build chain models that include not only environmental aspects, but interest in energy consumption and chain models that pay attention to greenhouse gas emissions [54].

The presented theoretical aspects of various innovative supply chain concepts indicate the interest of scientists and researchers in them, which may contribute to changing the approach to chain management and, above all, to reducing the negative environmental impact of logistics processes. A selection of specific strategies and their impact on emissions is indicated in Table 1. The implementation of strategies based on classical logistics, and supply chain objectives based on time, quality, and cost, do not commit to environmental goals, and thus the indicated impact on GHG emissions is high and simultaneously negative in terms of pollution reduction. In contrast, modern (based on sustainable development principles) or pro-environmental strategies (e.g., green, sustainable or resilient supply chain) can be considered, in which the environmental goal is one of the priorities, and thus the impact on GHG reductions will be high. In the context of, e.g., short supply chain strategies, the neutral, positive or negative impact can be said, as it will depend on the type of product offered in the chain and not only on the strategy implemented.

Table 1. GHG impacts of selected supply chain strategies.

\begin{tabular}{|c|c|c|c|}
\hline & & Strategy of the Supply Chain & $\begin{array}{l}\text { Reduction in GHG Emission; } \\
\text { Impact: ( }- \text { ) Negative = More } \\
\text { Emission; (+) Positive = Reduction }\end{array}$ \\
\hline \multirow{8}{*}{ strategy assumptions } & \multirow{3}{*}{$\begin{array}{l}\text { traditional, efficiency-based: } \\
\text { cost, quality, time }\end{array}$} & Lean supply chain & $(-)$ \\
\hline & & Agile supply chain & $(-)$ \\
\hline & & Long supply chain & $(-)$ \\
\hline & \multirow{5}{*}{$\begin{array}{l}\text { modern (innovative), based } \\
\text { on environmental } \\
\text { performance and efficiency }\end{array}$} & Low-carbon supply chain & $(+)$ \\
\hline & & Green supply chain & $(+)$ \\
\hline & & Sustainable supply chain & $(+)$ \\
\hline & & Short supply chain & $(+)(-)$ \\
\hline & & Responsible supply chain & $(+)$ \\
\hline
\end{tabular}

Source: own elaboration.

Irrespective of the choice of strategy, it should be pointed out that the means of delivery and the choice of means of transport are, independently of the chain strategy, one of the most important elements for the implementation of processes in the chain and, therefore, also influence the degree and scale of pollution they cause. Their analysis and elimination of bottlenecks may contribute to the success of the implemented strategy.

The supply chain management approach requires the use of various management tools. In the literature and business practice, we encounter more or less classical approaches. The more classic ones, based on the time-quality-cost triad, do not include sustainable development as an element that supports activities or contributes to increasing the competitiveness of the chain. They traditionally refer to long, slow chains for mass products. Until the times when there was no need to implement sustainable development principles, they were considered the most effective and desirable solutions. However, changing global policies towards environmental protection require changes in supply chain configurations. The traditional approach may be cost effective, but not environmentally, which means that there is a need to make changes even in the traditional approach. Modern, pro-environmental chain strategies can serve as a basis for change and reconfiguration of existing solutions. Nowadays, traditional concepts cannot be literally implemented, each new solution must take environmental aspects into account. Therefore, the analysis of the above-mentioned chains and their assumptions was aimed to show the modern approach, and to indicate 
(thanks to the simulations) in which areas, in which part of the chain, for selected products, pro-environmental concepts should be implemented.

\section{Materials and Methods}

Analysing performance of complex systems, such as supply chain, is a difficult task for decision makers. Use of analytical methods is not always possible, especially considering multiplicity of variables, parameters, and random factors existing in large systems. Hence, discrete event computer simulation (DES) is an alternative method to investigate operation of a complex system. Discrete event simulation is a flexible modelling method characterized by the ability to represent complex behaviour and permits the evaluation of operating performance prior to the implementation of a system. It enables companies to investigate interactions between individual members of a supply chain and their environment and also perform powerful what-if analyses leading them to better planning decisions [55].

Dynamic simulation models are recognized as a suitable tool to observe and predict supply chain behaviours over time. The simulation models are especially useful for analysis when the impacts of disruptions on SC performance need to be computed under conditions of time-dependant changes [56].

\subsection{Simulation Model Design-Supplier Selection Analysis}

We model a total of four global supply chains. Two for food suppliers (specifically apples) and two for clothing suppliers. The objective is to calculate the $\mathrm{CO}_{2}$ released through the means of transport of products and goods for the different chains, taking into account random elements.

Poland is one of the three largest apple producers in the world. However, in chain shops in Poland you can get apples not only from Poland, but even from Chile and New Zealand.

The following supply chains for two apple suppliers will be compared. Place of delivery: Szczecin, Poland:

(1) Supplier from Poland in the Mazovia region-car transport;

(2) Supplier from New Zealand - transport by truck and ship.

The following two supply chains for clothing suppliers will also be compared. Place of delivery: Szczecin, Poland:

(1) Supplier from Italy—car transport;

(2) Supplier from China-transport by truck and ship.

Using the possibilities of simulation modelling, we want to analyse scenarios of use in the supply chain of a fleet of cars that emits more (Euro III class and below-Table 2) or less (Euro IV class and above) $\mathrm{CO}_{2}$ into the atmosphere. In addition, simulation software gives the possibility to introduce various types of disturbances in the route, e.g., breakdowns, road congestion-which cause an increase in fuel consumption and thus the majority of $\mathrm{CO}_{2}$ emitted.

Table 2. Emission values for vehicles with petrol engine.

\begin{tabular}{ccc}
\hline Emission Norm & Valid From & Emission Factor $\mathbf{C O}_{\mathbf{2}}$ \\
\hline Euro I & $12 / 92$ & 2.72 \\
Euro II & $01 / 97$ & 2.20 \\
Euro III & $01 / 00$ & 2.30 \\
Euro IV & $01 / 05$ & 1.00 \\
Euro V & $09 / 09$ & 1.00 \\
Euro VI & $08 / 14$ & 1.00 \\
\hline
\end{tabular}

Source: own elaboration.

Scenarios will therefore be analysed as follows:

- Due to the use of the truck fleet:

- Class Euro III (older vehicle fleet); 
- Class Euro IV (newer vehicle fleet);

- Due to random factors along the route:

- Low impact of the random factors;

- High impact of the random factors.

In order to compare the amount of $\mathrm{CO}_{2}$ emitted into the atmosphere, it was assumed that the transport would be for the same amount of apples-1000 tonnes and the same amount of clothes-100 tonnes.

The following formula (IBM Knowledge Center, 2016) was used to calculate $\mathrm{CO}_{2}$ emissions for trucking:

$$
\mathrm{CO}_{2}=(\text { number of kilometres }+ \text { fuel consumption }) \cdot \text { emission factor }
$$

The amount of $\mathrm{CO}_{2}$ emitted for trucks is calculated using the formula above, where the number of driven kilometres is added together with the total amount of fuel consumed and this result is multiplied by the emission factor (for a given truck type) from Table 2. Fuel consumption was assumed as a random variable with normal distribution, as the driving conditions of trucks are different and vary depending on weather and terrain factors.

To calculate $\mathrm{CO}_{2}$ emissions for shipping, the formula presented in the article by Szelangiewicz and Żelazny [51] was used for the reference line $\mathrm{CO}_{2}$ emission standard for the following:

$$
\begin{aligned}
& \text { refrigerated cargo carriers : } L=227 \cdot D W T^{-0.244} \text { (for apples supply chain) } \\
& \text { container ships : } L=140 \cdot D W T^{-0.244} \text { (for clothes supply chain) }
\end{aligned}
$$

The result represents the number of grams/tonne of $\mathrm{CO}_{2}$ emissions, where DWT represents the deadweight of the ship (in our case, 20,000 thousand tonnes were assumed for a medium-sized refrigerator cargo carrier and container ship). The summary input data

\begin{tabular}{|c|c|c|c|c|}
\hline & Supply Chain Links & $\begin{array}{c}\text { Number of } \\
\text { Tonnes of } \\
\text { Apples/Clothes }\end{array}$ & Type of Transport & $\begin{array}{l}\text { Number of } \\
\text { Kilometres }\end{array}$ \\
\hline \multirow{2}{*}{$\begin{array}{c}\text { Apples } \\
\text { supply chains }\end{array}$} & Mazovia region (PL)-Szczecin (PL) & 1000 & truck transport & \multirow{2}{*}{$\begin{array}{c}740 \\
150+420 \text { (truck) } \\
21,100(\text { ship })\end{array}$} \\
\hline & New Zealand-Panama-Hamburg-Szczecin (PL) & 1000 & transport by truck and ship & \\
\hline \multirow{2}{*}{$\begin{array}{l}\text { Clothes } \\
\text { supply chains }\end{array}$} & Modena (Italy)-Szczecin (PL) & 100 & truck transport & \multirow{2}{*}{$\begin{array}{c}1420 \\
20+420 \text { (truck) } \\
19,400 \text { (ship) }\end{array}$} \\
\hline & Hong Kong-Suez Canal-Hamburg-Szczecin (PL) & 100 & transport by truck and ship & \\
\hline
\end{tabular}
for the simulation model are shown in Table 3.

Table 3. Input data to the simulation model.

Source: own elaboration.

Described supply chains were modelled in the simulation package Arena Rockwell software (version 14). This environment can simulate any complex system, including complex supply chains.

The versatility of this tool allows mapping the processes occurring in each type of system. In this study to validate the model a certain number of experiments were run with different sets of inputs and several validation techniques were applied to the model, such as internal consistency checks, checking the correctness of the model (check errors), watching animation of process.

In order to assure reliable results within the scope of our research, 10 replications have been created (for reducing output randomness) for each of the 16 (4types of chains $\times 2$ types of car fleet $\times 2$ types of random factors) simulation scenarios, which results in 160 simulations. 


\subsection{Experimental Results}

For the assumptions given earlier for the model, simulation experiments were carried out. The results are presented in this section in figures and tables. The aim of the conducted research was to compare the $\mathrm{CO}_{2}$ released into the atmosphere for the analysed supply chains for different scenarios. The comparison was constructed to compare the analysed chains in terms of the following:

- The amount of grams of $\mathrm{CO}_{2}$ emitted per kilometre of the chain;

- The amount of grams of $\mathrm{CO}_{2}$ emitted per tonne of goods transported.

The first comparison concerns the apple supply chain to Poland (to the city of Szczecin). The results are presented in Figure 5 and Table 4. The table shows the average results from 10 replications of the simulation due to the amount of $\mathrm{CO}_{2}$ emitted per kilometre of route in the supply chain.

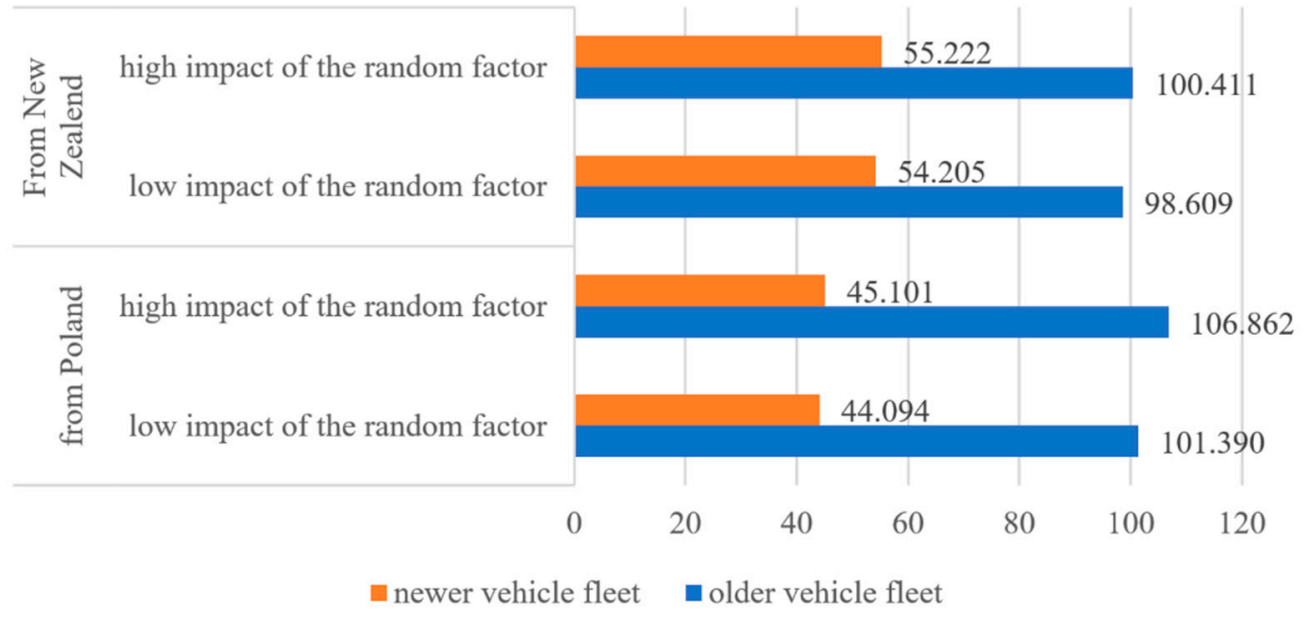

Figure 5. $\mathrm{CO}_{2}$ emission values per tonne of goods transported for analysed scenarios for apple suppliers. Source: own elaboration.

Table 4. $\mathrm{CO}_{2}$ emission values per kilometre of the supply chain for analysed scenarios for apple suppliers.

\begin{tabular}{ccccc}
\hline & \multicolumn{2}{c}{ From Poland } & \multicolumn{2}{c}{ From New Zealand } \\
\cline { 2 - 5 } & $\begin{array}{c}\text { Low Impact of the } \\
\text { Random Factors }\end{array}$ & $\begin{array}{c}\text { High Impact of the } \\
\text { Random Factors }\end{array}$ & $\begin{array}{c}\text { Low Impact of the } \\
\text { Random Factors }\end{array}$ & $\begin{array}{c}\text { High Impact of the } \\
\text { RANDOM factors }\end{array}$ \\
\hline older vehicle fleet & 3.271 & 3.425 & 1.736 & 1.776 \\
newer vehicle fleet & 1.409 & 1.456 & 0.751 & 0.776 \\
\hline
\end{tabular}

Source: own elaboration.

Indeed, the values for the supply chain from New Zealand are lower than for the chain from Poland (due to the long distance and transport by ship, which emits less $\mathrm{CO}_{2}$ than road transport). Unfortunately, a large proportion of transport companies serving the Polish market are still using Euro III class trucks. However, the conclusion is also striking, that the type of car fleet used (EURO IV or higher) has a much greater influence on the amount of $\mathrm{CO}_{2}$ than random factors, even though the simulation model in these scenarios sets their influence high.

In the context of the results of Table 4, it is interesting to see the results in Figure 5 where the amount of $\mathrm{CO}_{2}$ emitted per tonne of goods transported is shown. This time, transport from Poland turns out to emit less $\mathrm{CO}_{2}$ in the case of transport using the new truck fleet (about $17 \%$ less) and only slightly more in the case of transport using the old fleet (under the same assumption in relation to the chain from New Zealand). Again, the influence of random factors appears to be less important-differences of a few percent at most. 
Further simulation experiments were conducted for the clothing supply chain to Poland, according to the assumptions presented earlier. The results are presented in Table 5 and Figure 6.

Table 5. $\mathrm{CO}_{2}$ emission values per kilometre of the supply chain for analysed scenarios for clothes suppliers.

\begin{tabular}{ccccc}
\hline & \multicolumn{2}{c}{ From Italy } & \multicolumn{2}{c}{ From New Zealand } \\
\cline { 2 - 5 } & $\begin{array}{c}\text { Low Impact of the } \\
\text { Random Factor }\end{array}$ & $\begin{array}{c}\text { High Impact of the } \\
\text { Random Factor }\end{array}$ & $\begin{array}{c}\text { Low Impact of the } \\
\text { Random Factor }\end{array}$ & $\begin{array}{c}\text { High Impact of the } \\
\text { Random Factor }\end{array}$ \\
\hline older vehicle fleet & 3.277 & 3.345 & 0.260 & 0.269 \\
newer vehicle fleet & 1.416 & 1.454 & 0.113 & 0.115 \\
\hline
\end{tabular}

Source: own elaboration.

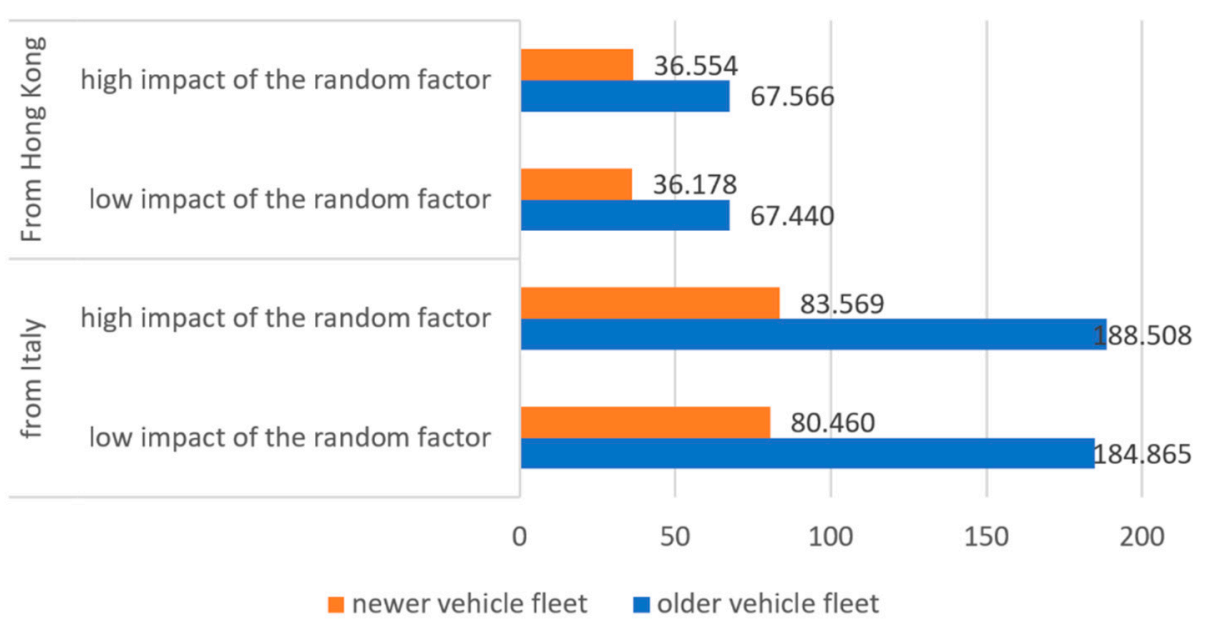

Figure 6. $\mathrm{CO}_{2}$ emission values per tonne of goods transported for analysed scenarios for clothes suppliers. Source: own elaboration.

From Table 5 it can be observed that the amount of $\mathrm{CO}_{2}$ emitted per kilometre for the Italian chain is several times higher than for the supply chain from Hong Kong. This applies to the use of both new and older car fleets. The difference is much higher than for the apple supply chain, since the distance (for car transport) in Italy is twice as high as for the apple supply chain.

Figure 6 shows the results of $\mathrm{CO}_{2}$ emitted per tonne of goods transported, here again the supply chain from Italy was found to be worse. When using a newer fleet of cars, the results more than doubled, when using an older fleet of cars the results almost tripled. In addition, the greater influence of random factors increases emissions by another few percent.

The results in Figure 6 (transport of clothes), unlike in the case of the transport of apples (Figure 5), show a much higher difference in $\mathrm{CO}_{2}$ emissions per tonne for a supply chain using only car transport than for a mixed supply chain (ship + car transport). The reason for this is the much greater distance from Italy to Poland on the one hand (the disproportion of $\mathrm{CO}_{2}$ emitted by cars compared to sea transport increases), but also the smaller amount of tonnage transported in the case of clothes.

\section{Findings and Discussion}

Coordinated decision-making, related to the optimisation of strategic and operational decisions that consider greenhouse gas emissions, must be an important element in influencing changes in emissions [5,25,57-61]. As the study shows, decisions concerning the choice of means of transport, and consequently the mode of delivery, are of strategic im- 
portance in the context of implementing new chain strategies and reconfiguring (adapting to environmental objectives) existing ones.

There is no doubt that almost all logistical decisions affect the actual amount of emissions [5]. Supporting changes in chains should be done by using appropriate management tools, both qualitative and quantitative. In the context of changing and re-configuring chains to be eco-friendlier and more non-polluting, the following models should be used [59]: operations management (OM), technology investment (TI), and supply chain design and co-ordination (SCD-C).

The analysis of the literature and case studies makes it possible to point out that within modern strategies a lot of attention is paid to environmental aspects, but one of the weaknesses is logistics and process execution, so it is important to continuously improve logistics processes to make them more efficient and environmentally friendly, and this will allow for active transformation and creation of new strategies into a sustainable alternative to traditionally functioning chains.

Logistics decisions, infrastructure, suprastructure and the nature of the processes carried out in the chains contribute to the continuous emission of pollutants through the chains. The mitigation measures indicated, including proposals for new strategies, should be implemented in order to diversify the risk of increasing pollution, as well as to operate the most efficient and sustainable chains possible. There are solutions in the literature that should be promoted. As an example, the creation of LCSCM-low carbon supply chain management [60], which should be combined with other pro-environmental concepts supported by scientific methods and models. Implementing LSCM as one of the possible strategies requires participating organisations to communicate, share information as well as risks and threats, collaborate and integrate their business processes with the objectives of the entire chain, in order to react quickly enough to market demands and changing conditions, and to make the right business decisions quickly and efficiently [61].

A number of scientific studies, including Schmitt et.al., [62] indicate that global products have lower environmental impacts because transport distance is not the most important factor in improving the sustainability of food products. Short supply chains (especially dedicated to food) are more economically beneficial for producers, while global supply chains generate lower environmental impacts in terms of their carbon footprint and food miles per unit of product [63]. At the same time, it should be pointed out that SFSC have a positive impact on environmental sustainability through externalities such as rural development, awareness creation, animal welfare, biodiversity, adoption of greener production methods and reduction in environmental pollution. It is therefore necessary to consider different options that will be most beneficial for all stakeholders, products and the environment. There is no doubt that the potential for innovative logistical solutions indicates that these should be implemented, but they entail significant implementation costs, which is an insurmountable barrier for many local producers. The implementation of innovative solutions must be properly thought out and implemented in order to maximise the potential effects. There is no doubt that it is necessary to use a scientific basis and choose a strategy, whether green, sustainable, low-carbon or short, according to the nature of the product, the structure of the chain and the relations that exist between the links. In each case, environmental aspects should be raised to a level at least as important as that of economic efficiency, quality and time.

However, the choice of a particular strategy to eliminate pollution in the chain should depend on the product and the factors that affect it, and be preceded by a thorough analysis of the strengths and weaknesses, barriers and benefits of the strategy.

\section{Conclusions}

Possible reconfigurations of supply chain management practices, and shifts towards greener and more environmentally friendly management and execution of supply chain processes need to be supported by appropriate modelling that integrates emissions issues (most notably $\mathrm{CO}_{2}$ in the chain) into management practices, providing managers with 
effective tools for decision support and chain reconfigurations. In order to reduce emissions, it is necessary to act systemically on all processes in the supply chain, to optimise the processes that have the greatest negative impact on the environment, and to change strategies. Changing strategies must not entail a reduction in the efficiency of the chain, so the optimum must be sought in terms of time, quality and costs, including by investing in newer, greener superstructure and looking for systemic solutions that allow chains to be shortened without a loss of process quality or an increase in chain costs.

The creation of sustainable supply chains and their assessment in terms of pollutant emissions must involve the need to optimise the processes occurring in them. It is about optimising order volumes, creating replenishment policies and shipping methods and quantities, production and consumption distances, considering emissions in all phases and elements. When optimizing chain operating costs, it is necessary to consider not only the processes themselves, but also, in connection with the creation of sustainable chains, the costs associated with emissions and the emission of pollutants themselves during the execution of processes, and to find ways of eliminating or reducing them.

Taking care of the environment should become a priority in the functioning and management of supply chains, even if it requires reorganising existing chain structures, changing strategies or investing in modern means of transport and storage. Nowadays, satisfying consumers' needs is not only about delivering the expected products, but also about meeting social and environmental needs, including the elimination and reduction in the negative impact of logistics activities on the natural environment. It is therefore necessary to find motivation and cost mechanisms, which should be seen as ways of reducing human impact on the environment, including greenhouse gas emissions. Organisational aspects should also be added to these mechanisms, including changes in strategies and ways of managing the chain.

Changing strategy is not easy and it must be considered that modern concepts are often in their infancy, while global networks have been optimising their efficiency for decades. It is therefore worth increasing confidence in innovative solutions and supporting more tailored solutions to solve problems generated by supply chains and affecting the environment.

Author Contributions: Conceptualization, methodology, validation, formal analysis, investigation, resources, writing — original draft preparation, writing—review and editing, visualization-B.T., T.W. All authors have read and agreed to the published version of the manuscript.

Funding: Publication financed by the Institute of Management, University of Szczecin, Poland.

Institutional Review Board Statement: Not applicable.

Informed Consent Statement: Not applicable.

Data Availability Statement: Not applicable.

Conflicts of Interest: The authors declare no conflict of interest.

\section{References}

1. Castellano, D.; Gallo, M.; Grassi, A.; Santillo, L.C. The effect of GHG emissions on production, inventory replenishment and routing decisions in a single vendor-multiple buyers supply chain. Int. J. Prod. Econ. 2019, 218, 30-42. [CrossRef]

2. Martí, J.M.C.; Tancrez, J.-S.; Seifert, R.W. Carbon footprint and responsiveness trade-offs in supply chain network design. Int. J. Prod. Econ. 2015, 166, 129-142. [CrossRef]

3. EU Emissions Trading System (EU ETS). Available online: https:/ / ec.europa.eu/clima/policies/ets_en (accessed on 1 February 2021).

4. He, P.; Zhang, W.; Xu, X.; Bian, Y. Production lot-sizing and carbon emissions under cap-and-trade and carbon tax regulations. J. Clean. Prod. 2015, 103, 241-248. [CrossRef]

5. Chelly, A.; Nouira, I.; Frein, Y.; Hadj-Alouane, A.B. On The consideration of carbon emissions in modelling-based supply chain literature: The state of the art, relevant features and research gaps. Int. J. Prod. Res. 2018, 57, 4977-5004. [CrossRef]

6. Barbosa-Póvoa, A.P.; Da Silva, C.; Carvalho, A. Opportunities and challenges in sustainable supply chain: An operations research perspective. Eur. J. Oper. Res. 2018, 268, 399-431. [CrossRef] 
7. Rajeev, A.; Pati, R.K.; Padhi, S.S.; Govindan, K. Evolution of sustainability in supply chain management: A literature review. J. Clean. Prod. 2017, 162, 299-314. [CrossRef]

8. Jabbour, C.J.C.; Neto, A.S.; Gobbo, J.A., Jr.; de Souza Ribeiro, M.; de Sousa Jabbour, A.B.L. Eco-innovations in more sustainable supply chains for a low-carbon economy: A multiple case study of human critical success factors in Brazilian leading companies. Int. J. Prod. Econ. 2015, 164, 245-257. [CrossRef]

9. Ghosh, P.; Jha, A.; Sharma, R.R.K. Managing carbon footprint for a sustainable supply chain: A systematic literature review. Mod. Supply Chain. Res. Appl. 2020, 2, 123-141. [CrossRef]

10. Van Der Vorst, J.; Van Der Zee, D.-J.; Tromp, S.-O. Simulation modelling for food supply chain redesign. In Delivering Performance in Food Supply Chains; Woodhead Publishing: Sawston, UK, 2010; pp. 387-415.

11. Homayouni, Z.; Pishvaee, M.S.; Jahani, H.; Ivanov, D. A robust-heuristic optimization approach to a green supply chain design with consideration of assorted vehicle types and carbon policies under uncertainty. Ann. Oper. Res. 2021, 1-41. [CrossRef]

12. Schreiber, L. Optimization and simulation for sustainable supply chain design. In Digital Transformation in Maritime and City Logistics: Smart Solutions for Logistics. Proceedings of the Hamburg International Conference of Logistics (HICL); Epubli GmbH: Berlin, Germany, 2019; Volume 28, pp. 271-298.

13. Xu, Z.; Elomri, A.; Pokharel, S.; Mutlu, F. The Design of Green Supply Chains under Carbon Policies: A Literature Review of Quantitative Models. Sustainability 2019, 11, 3094. [CrossRef]

14. Zheng, X.; Yu, H.; Atkins, A. An Overview of Simulation in Supply Chains. In Advanced Design and Manufacture to Gain a Competitive Edge; Springer: London, UK, 2008; pp. 407-416.

15. Owen, C.; Albores, P.; Greasley, A.; Love, D. Simulation in the supply chain context: Matching the simulation tool to the problem. In Proceedings of the Operational Research Society Simulation Workshop 2010 (SW10), Worcestershire, UK, $23-24$ March 2010.

16. Hoffa-Dabrowska, P.; Grzybowska, K. Simulation Modeling of the Sustainable Supply Chain. Sustainability 2020, $12,6007$. [CrossRef]

17. Bové, A.T.; Swartz, S. Starting at the source: Sustainability in supply chains. McKinsey Sustain. Resour. Product. 2016, 4, 36-43.

18. Why Freight Matters to Supply Chain Sustainability. Available online: https://www.epa.gov/smartway/why-freight-matterssupply-chain-sustainability (accessed on 4 January 2021).

19. Hovelaque, V.; Bironneau, L. The carbon-constrained EOQ model with carbon emission dependent demand. Int. J. Prod. Econ. 2015, 164, 285-291. [CrossRef]

20. Huang, Y.A.; Weber, C.L.; Matthews, H.S. Categorization of scope 3 emissions for streamlined enterprise carbon footprinting. Environ. Sci. Technol. 2009, 43, 8509-8515. [CrossRef]

21. EN01 Energy and Non-Energy-Related Greenhouse Gas Emissions, European Environment Agency. Available online: https: //www.eea.europa.eu/data-and-maps/indicators/en01-energy-related-greenhouse-gas-emissions/en01 (accessed on 21 April 2021).

22. Seuring, S.; Müller, M. From a literature review to a conceptual framework for sustainable supply chain management. J. Clean. Prod. 2008, 16, 1699-1710. [CrossRef]

23. Hallinger, P. Analyzing the intellectual structure of the Knowledge base on managing for sustainability, 1982-2019: A metaanalysis. Sustain. Dev. 2020, 28, 1493-1506. [CrossRef]

24. Nath, V.; Agrawal, R. Agility and lean practice as antecedents of Supply Chain socialustainability. Int. J. Oper. Prod. Manag. 2020, 40, 1589-1611. [CrossRef]

25. Das, C.; Jharkharia, S. Low carbon supply chain: A state-of-the-art literature review. J. Manuf. Technol. Manag. 2018, 29, 398-428. [CrossRef]

26. Shaharudin, M.S.; Fernando, Y.; Jabbour, C.J.C.; Sroufe, R.; Jasmi, M.F.A. Past, present, and future low carbon supply chain management: A content review using social network analysis. J. Clean. Prod. 2019, 218, 629-643. [CrossRef]

27. Böttcher, C.F.; Müller, M. Drivers, Practices and Outcomes of Low-carbon Operations: Approaches of German Automotive Suppliers to Cutting Carbon Emissions. Bus. Strat. Environ. 2015, 24, 477-498. [CrossRef]

28. Fernando, Y.; Hor, W.L. Impacts of energy management practices on energy efficiency and carbon emissions reduction: A survey of malaysian manufacturing firms. Resour. Conserv. Recycl. 2017, 126, 62-73. [CrossRef]

29. Damert, M.; Feng, Y.; Zhu, Q.; Baumgartner, R.J. Motivating low-carbon initiatives among suppliers: The role of risk and opportunity perception. Resour. Conserv. Recycl. 2018, 136, 276-286. [CrossRef]

30. Mao, Z.; Zhang, S.; Li, X. Low carbon supply chain firm integration and firm performance in China. J. Clean. Prod. 2017, 153, 354-361. [CrossRef]

31. Zsidisin, G.A.; Siferd, S.P. Environmental purchasing: A framework for theory development. Eur. J. Purch. Supply Manag. 2001, 7, 61-73. [CrossRef]

32. Tundys, B.; Wisniewski, T.T. Green Supply Chain Management Evaluation for Organic Products: Theoretical and Empirical Point of View. Oper. Supply Chain Manag. Int. J. 2020, 14, 73-82. [CrossRef]

33. Wiśniewski, T.; Tundys, B. Greening across supply chain-Analysis of the empirical studies. Res. Logist. Prod. 2018, 8, 53-66. [CrossRef]

34. Fernando, Y.; Sharon, S.S.T.; Wahyuni-Td, I.S.; Tundys, B. The effects of reverse logistics on cost control abilities: An insight into manufacturing companies in Malaysia. Int. J. Value Chain. Manag. 2017, 8, 285-306. [CrossRef] 
35. Hongjuan, Y.; Jing, Z. The Strategies of Advancing the Cooperation Satisfaction among Enterprises Based on Low Carbon Supply Chain Management. Energy Procedia 2011, 5, 1225-1229. [CrossRef]

36. Srivastava, S. Green supply-chain management: A state-of-the-art literature review. Int. J. Manag. Rev. 2007, 9, 53-80. [CrossRef]

37. Fahimnia, B.; Sarkis, J.; Davarzani, H. Green supply chain management: A review and bibliometric analysis. Int. J. Prod. Econ. 2015, 162, 101-114. [CrossRef]

38. Brandenburg, M.; Govindan, K.; Sarkis, J.; Seuring, S. Quantitative models for sustainable supply chain management: Developments and directions. Eur. J. Oper. Res. 2014, 233, 299-312. [CrossRef]

39. Marchi, B.; Zanoni, S. Supply Chain Management for Improved Energy Efficiency: Review and Opportunities. Energies 2017, 10, 1618. [CrossRef]

40. Tidy, M.; Wang, X.; Hall, M. The role of Supplier Relationship Management in reducing Greenhouse Gas emissions from food supply chains: Supplier engagement in the UK supermarket sector. J. Clean. Prod. 2016, 112, 3294-3305. [CrossRef]

41. Seuring, S.; Müller, M. Core issues in sustainable supply chain management-A Delphi study. Bus. Strat. Environ. 2008, 17, 455-466. [CrossRef]

42. Noh, J.; Kim, J.S. Cooperative green supply chain management with greenhouse gas emissions and fuzzy demand. J. Clean. Prod. 2019, 208, 1421-1435. [CrossRef]

43. Sarkis, J.; Zhu, Q. Environmental sustainability and production: Taking the road less travelled. Int. J. Prod. Res. 2018, 56, 743-759. [CrossRef]

44. Kusi-Sarpong, S.; Gupta, H.; Sarkis, J. A supply chain sustainability innovation framework and evaluation methodology. Int. J. Prod. Res. 2019, 57, 1990-2008. [CrossRef]

45. Vittersø, G.; Torjusen, H.; Laitala, K.; Tocco, B.; Biasini, B.; Csillag, P.; De Labarre, M.D.; Lecoeur, J.-L.; Maj, A.; Majewski, E.; et al. Short Food Supply Chains and Their Contributions to Sustainability: Participants' Views and Perceptions from 12 European Cases. Sustainability 2019, 11, 4800. [CrossRef]

46. Berti, G.; Mulligan, C. Competitiveness of Small Farms and Innovative Food Supply Chains: The Role of Food Hubs in Creating Sustainable Regional and Local Food Systems. Sustainability 2016, 8, 616. [CrossRef]

47. Rong, A.; Akkerman, R.; Grunow, M. An optimization approach for managing fresh food quality throughout the supply chain. Int. J. Prod. Econ. 2011, 131, 421-429. [CrossRef]

48. Burgess, P.R.; Sunmola, F.T. Prioritising Requirements of Informational Short Food Supply Chain Platforms Using A Fuzzy Approach. Procedia Comput. Sci. 2021, 180, 852-861. [CrossRef]

49. Paciarotti, C.; Torregiani, F. The logistics of the short food supply chain: A literature review. Sustain. Prod. Consum. 2021, 26, 428-442. [CrossRef]

50. Thomé, K.M.; Cappellesso, G.; Ramos, E.L.A.; Duarte, S.C.D.L. Food Supply Chains and Short Food Supply Chains: Coexistence conceptual framework. J. Clean. Prod. 2021, 278, 123207. [CrossRef]

51. Manteghi, Y.; Arkat, J.; Mahmoodi, A.; Farvaresh, H. Competition and cooperation in the sustainable food supply chain with a focus on social issues. J. Clean. Prod. 2021, 285, 124872. [CrossRef]

52. Marchi, B.; Zanoni, S.; Ferretti, I.; Zavanella, L.E. Stimulating Investments in Energy Efficiency Through Supply Chain Integration. Energies 2018, 11, 858. [CrossRef]

53. Marchi, B.; Zanoni, S.; Zavanella, L.E.; Jaber, M.Y. Supply chain models with greenhouse gas emissions, energy usage, and imperfect process under different coordination decisions. Int. Prod. Econ. 2019, 211, 145-153. [CrossRef]

54. Chang, Y.; Makatsoris, M. Supply chain modelling using simulation. Int. J. Simul. 2020, 2, $24-30$.

55. Ivanov, D. Structural Dynamics and Resilience in Supply Chain Risk Management; Springer: New York, NY, USA, 2018.

56. Szelangiewicz, T.; Żelazny, K. Poziom emisji $\mathrm{CO}_{2}$ jako kryterium projektowe współczesnych statków transportowych. Pr. Nauk. Politech. Warsz. Transp. 2013, 98, 625-635.

57. Memari, A.; Rahim, A.R.A.; Ahmad, R.; Hassan, A. A literature review on green supply chain modelling for optimising $\mathrm{CO}_{2}$ emission. Int. J. Oper. Res. 2016, 26, 509. [CrossRef]

58. Sroufe, R. Integrated Management: How Sustainability Creates Value for Any Business; Emerald Group Publishing: Bingley, UK, 2018.

59. Schmitt, E.; Galli, F.; Menozzi, D.; Maye, D.; Touzard, J.M.; Marescotti, A.; Six, J.; Brunori, G. Comparing the sustainability of local and global food products in Europe. J. Clean. Prod. 2017, 165, 346-359. [CrossRef]

60. Malak-Rawlikowska, A.; Majewski, E.; Wąs, A.; Borgen, S.O.; Csillag, P.; Donati, M.; Freeman, R.; Hoàng, V.; Lecoeur, J.L.; Mancini, M.C.; et al. Measuring the Economic, Environmental, and Social Sustainability of Short Food Supply Chains. Sustainability 2019, 11, 4004. [CrossRef]

61. González-Azcárate, M.; Maceín, J.L.C.; Bardají, I. Why buying directly from producers is a valuable choice? Expanding the scope of short food supply chains in Spain. Sustain. Prod. Consum. 2021, 26, 911-920. [CrossRef]

62. Mittal, A.; Krejci, C.C.; Craven, T.J. Logistics Best Practices for Regional Food Systems: A Review. Sustainability 2018, 10, 168. [CrossRef]

63. Mastronardi, L.; Marino, D.; Cavallo, A.; Giannelli, A. Exploring the role of farmers in short food supply chains: The case of Italy. Int. Food Agribus. Manag. Rev. 2015, 18, 109-130. 